\title{
SUM MARY
}

Bilyk Roman. Development and theoretical substantiation of the system of professional training of future specialists in labor protection.

In the article the system of professional training of future specialists of labour protection area in institutions of professional education is considered, under which we understand the relation of the given processes, means and methods of their realization, necessary for maintenance of predicted influence on educational process of training of future specialists of labour protection area with high level of professional and universal qualities. The main characteristics of this system are: structure, hierarchy, integrity, ideological integrity, relationship with the environment, ability to adapt to changing external factors. The model of the system of professional training of future specialists in labor protection in the institutions of professional education has been constructed and its main components have been substantiated, in particular: target content, operational, procedural, resultative blocks.

It is defined, that improvement of educational and methodological maintenance, methods of teaching disciplines of a professional direction, optimization of the process of conducting lessons, organization of independent work of students and the pedagogical control raises an indicator of the level of formation of competence of the future expert.

In our studies we consider the system of professional training of future occupational safety specialists as an interdependent totality of certain components (blocks), each of which is characterized by integral properties and forming a stable unity between themselves in the organization of pedagogical process of forming professional competences of future occupational safety specialists in vocational education institutions. In the proper sense, the modern professional training of future occupational safety specialists we interpret as a complex pedagogical system, which is characterized by a specific content, hierarchy of structural components, forms of relations, which are a reflection of cause-and-effect relations and unite forms and methods of educational process organization and ways to solve urgent contradictions arising during professional training of specialist of «Bachelor» and «M aster» levels of higher education.

Key words: labor protection, professional education, professional training system, educational environment, professional competence.

\section{Удк 378:504.06}

Світлана Бондарчук

Льотна академія Національного авіаційного університету

ORCID ID 0000-0001-5636-328X

DOI 10.24139/2312-5993/2020.09/120-130

\section{ДО ПИТАННЯ ПРО ФОРМУВАННЯ ДБАЙЛИВОГО СТАВЛЕННЯ ДО ДОВКІЛЛЯ МАЙБУТНІХ АВІАЦІЙНИХ ФАХІВЦІВ У ПРОЦЕСІ ПРОФЕСІЙНОЇ пІдготовки}

У статті розглянуто шляхи формування дбайливого ставлення до довкілля майбутніх авіаційних фахівців у процесі профресійної підготовки. Розглянуто місце вищої школи в сталому розвитку. Проаналізовано роботи сучасних науковців, які займалися дослідженням зазначеної тематики. На прикладі Льотної академії Національного авіаційного університету запропоновано розглянути становлення дбайливого, небайдужого відношення до довкілля шляхом екологізації освіти та 
проведення різноманітних екологічних заходів через активне залучення курсантів/студентів до цього прочесу. Запропоновані шляхи вирішення проблеми.

Ключові слова: навколишнє середовище, сталий розвиток, освітній прочес, екологізація освіти, авіаційні фрахівці, екологічна культура, екологічна свідомість.

Постановка проблеми. Відомо, що сучасне українське суспільство розвивається відповідно до сталого розвитку, але специфікою нашої держави $\epsilon$ неузгодженість між великими планами та реаліями. I ми можемо спостерігати, що в умовах надзвичайного зростання зовнішніх впливів на економічне, соціальне, культурне й політичне життя нашого суспільства, проблема розвитку глобальних процесів стає центральним питанням виживання. I найголовніші серед них, на відміну від світової тенденції, сучасні екологічні проблеми України, які переважно спричинені неузгодженістю процесів освітнього, економічного та природно-ресурсного розвитку.

Сталий розвиток передбачає збалансованість розвитку економічної, екологічної та соціальної систем і одночасну їх здатність до саморегуляції та відтворення. А освіта, на наш погляд, повинна стати зв'язком між усіма компонентами сталого розвитку. І саме освітній процес вищої школи, коли мова йде про підготовку висококваліфікованих фахівців, повинен стати форвардом у напрямку дбайливого ставлення до довкілля у своїй майбутній професії.

Аналіз актуальних досліджень. Питанням екологізації освіти, формування екологічної свідомості, вивчення компетентнісного підходу до проблеми екологічної освіти у ЗВО, формування професійної екологічної компетентності студентів університету в контексті завдань сталого розвитку, становлення екологічної культури та екологічної компетентності висвітлені у працях сучасних українських науковців Г.Білявського, Л. Большака, О. Варго, М. Кісельова, Ю. Саунової, М. Складановської, О. Матеюка, Ю. Туниці, Г. Пухальської та інших. Незважаючи на досить велику кількість наукових публікацій, на практиці залишаються невирішеними питання екологізації освіти, а саме практичного втілення ідеї формування екологічної культури, мислення, свідомості під час навчально-виховного процесу у вищій школі.

Мета статті. Ураховуючи актуальність і недостатнє розкриття проблеми, ми пропонуємо адаптовано до Льотної академії НАУ розглянути становлення дбайливого, небайдужого ставлення до довкілля. Одним із важливих чинників для збереження й відтворення довкілля $є$ відношення людини до навколишнього середовища, не в широкому розумінні, а на більш локальному рівні. I саме низький рівень екологічної свідомості, екологічної культури суспільства, призвели до значної деградації довкілля 
України, надмірного забруднення поверхневих і підземних вод, атмосферного повітря і ґрунтів, нагромадження в дуже великих кількостях шкідливих, у тому числі високотоксичних, відходів виробництва. Такі процеси тривали десятиріччями і призвели до різкого погіршення стану здоров'я людей, зменшення народжуваності та збільшення смертності, збільшення еміграції, а це загрожує існуванню народу України.

Тому метою роботи стало визначення шляхів формування дбайливого ставлення до довкілля майбутніх авіаційних фахівців Льотної академії НАУ (ЛА НАУ) у процесі професійної підготовки.

Для реалізації поставленої мети необхідно було вирішити такі завдання:

- проаналізувати сучасний стан дослідження тематики;

- проаналізувати рівень екологічних знань студентів/курсантів ЗВО м. Кропивницький;

- описати досвід роботи ЛА НАУ в напрямі розвитку екологічної свідомості;

- окреслити шляхи розвитку ЛА НАУ в напрямі дбайливого ставлення до довкілля.

Методи дослідження. Для досягнення мети в роботі використовували такі наукові методи, як аналізу, синтезу, емпіричний метод.

Виклад основного матеріалу. Розглянемо декілька напрямів розвитку ЛА НАУ в напрямі дбайливого ставлення до довкілля в процесі підготовки авіаційних спеціалістів.

Одним із напрямів $\epsilon$ екологізація освіти. Протягом останніх 10 років нами було проведено дослідження рівня екологічних знань серед студентів та курсантів закладів освіти Кропивницького, який показав, що молодь не має ґрунтовних, системних знань про закони природи, про зв'язки в навколишньому середовищі. Програма «Екологія», для профільного навчання в 10-11 класах, повинна завершувати шкільну екологічну освіту, основою якої $€$ визначення місця України в сучасному світовому сталому розвитку за ступенем екологізації природокористування. Запропонований курс мав би дати не тільки уявлення, а й сформувати усвідомлення сучасних екологічних тенденцій: нового ставлення до природи; нової стратегії взаємодії з природою. Але, на жаль, випускники шкіл через вікові особливості не можуть повною мірою адаптувати екологічні знання, не мають сформованих екологічних уявлень про екологічні закони.

Дисципліна «Основи екології» на сьогодні практично знищена в непрофільних закладах освіти. Бачимо нині бажання керівництва ЛА НАУ 
звести екологію разом з географією та метеорологією, що є доцільно. Безумовно, підґрунтям для вивчення екології $\epsilon$ як географія, так і метеорологія, а також багато інших дисциплін. І тут ми простежуємо міждисциплінарні зв'язки, що $€$ важливими для цілісної, ґрунтовної підготовки сучасного фахівця. Але зводити три дисципліни в один навчальний предмет $€$ помилкою, тому що недоотримавши базові знання з екології в школі, молодь приходить у заклади вищої освіти неготовою в повному обсязі доповнити (отримати) ту базу знань, яка необхідна майбутньому спеціалісту в його професійній діяльності. Навчальний курс у вищій школі має адаптувати та інтегрувати теоретичні знання і практичний досвід, що стане в майбутньому основою гармонійного та сталого функціонування суспільства. Можна відмітити досягнення кафедри пошуку, рятування, авіаційної безпеки та спеціальної підготовки ЛА НАУ, яка ввела до навчального плану спеціальності 272 «Авіаційний транспорт» спеціалізації «Аварійне обслуговування та безпека на авіаційному транспорті» навчальну дисципліну «Екологічна безпека цивільної авіації». Мета цієї навчальної дисципліни $\epsilon$ вивчення впливу потенційно небезпечних факторів авіаційного комплексу, на основі чіткого розуміння основних закономірностей формування екологічної безпеки й управління безпекою. Але, на превеликий жаль, дана дисципліна викладається тільки для однієї спеціалізації.

Тому, ми вважаємо, що вирішення проблеми дбайливого ставлення до довкілля майбутніх авіаційних фахівців у процесі професійної підготовки можливе, серед іншого, через:

1) проведення «екологізації» всіх навчальних дисциплін, використовуючи міжпредметні зв'язки, а це можливо зробити коли і сам викладач буде мати екологічне мислення, пройшовши підготовку (перепідготовку) в дусі екологічного компонента сталого розвитку;

2) повернення «Основ екології» до обов'язкових дисциплін для вивчення у ЗВО;

3) введення дисципліни «Екологічна безпека цивільної авіації» в навчальні плани всіх спеціалізації ЛА НАУ;

4) розробку програм дисципліни з максимальним наближенням екологічних знань до специфіки професійної діяльності студента/курсанта;

5) створення у ЗВО екологозабезпечуючий менеджмент освітніх інновацій;

6) розробку й запровадження в закладах освіти концепції сталого екологічного розвитку, остаточною метою якої може стати отримання звання «Зеленого університету». Таке визначення використовується для 
визначення екологічного рівня ЗВО в ЄC («sustainability» (сталий розвиток) або «greencampus» (зелений університет)).

Таким чином, підготовка громадян із високим рівнем екологічних знань, екологічної свідомості й культури на основі нових критеріїв оцінки взаємовідносин людського суспільства та природи (не насильство, а гармонійне співіснування з нею!), повинна стати одним із головних важелів у вирішенні надзвичайно гострих екологічних і соціально-економічних проблем сучасної України. Екологічна освіта, як цілісне культурологічне явище, що включає процеси навчання, виховання, розвитку особистості, повинна спрямовуватися на формування екологічної культури як складової системи національного і громадянського виховання всіх верств населення України (у тому числі через екологічне просвітництво за допомогою громадських екологічних організацій), екологізацію навчальних дисциплін та програм підготовки, а також на професійну екологічну підготовку через базову екологічну освіту (Про концепцію екологічної освіти в України, 2001).

На прикладі ЛА НАУ розглянемо досвід формування дбайливого ставлення до довкілля майбутніх авіаційних фахівців у процесі професійної підготовки формування в напрямі дбайливого ставлення до довкілля.

Розуміючи відповідальність вищої освіти за формування екологічної свідомості серед молоді, ЛА НАУ з 2014 року розпочала планомірну роботу зі створення іміджу академії як «Академії екологічної». У 2015 році співробітниками та курсантами створена ГО «Еко-Альянс 4.0». У 2016 році Волонтерський ценрт спільно зі студентським самоврядуванням розробили флаєра та плакати, де пояснювалося, як сортувати сміття. За фінансової підтримки Міжнародного фонду соціальної адаптації (м. Київ) були замовлені та виготовлені урни для роздільного збору сміття, які були розставлені по навчальним корпусам ЛА НАУ з інформативними плакатами. Проведена пояснювальна робота з курсантами та співробітниками академії стосовно сортування. 3 того ж року, з ініціативи начальника Академії, на території 2-го навчального корпусу закладається Норвезький екологічний сквер, де висаджуються дерева, кущі та проводяться роботи зі створення водозабірної системи. Також варто відмітити, що, починаючи з 2011 року, щорічно в Академії у квітні місяці відбувається виставки: «Чорнобильська трагедія очами молоді», де курсанти виставляють свої малюнки.

У 2016 році у ЛА НАУ відбулося багато екологічних заходів. Серед іншого в квітні відбувся Еко-фест. Свої досягнення продемонстрували співробітники Кіровоградського обласного центру еколого-натуралістичної творчості учнівської молоді та Кіровоградського обласного центру туризму, 
краєзнавства та екскурсій учнівської молоді. Свою продукцію показали представники Кіровоградського навчально-виробничого підприємства Української громади глухих. Представники Кіровоградського обласного художнього музею, ГО «Сонячний зайчик», Кіровоградського обласного центру дитячої та юнацької творчості провели майстер-класи хенд-мейду. Вироби гончарства представила ГО «Високі Байраки Козацькі».

Також у квітні відбувся науковий екологічних семінар, на якому були присутні заступник голови ОДА, директор департаменту екології та природних ресурсів Кіровоградської ОДА, представники державної екологічної інспекції та Всеукраїнської громадської організації «Е-Екологія» та ін. На семінарі підняли питання важливості вирішення екологічних проблем громадою разом із органами влади, створення та функціонування Web-системи управління охороною навколишнього природного середовища, значення екологічного виховання з дитячого віку тощо.

28 вересня 2016 року в ЛА НАУ відбувся екологічний семінар «Екологічні проблеми водних ресурсів Кіровоградщини». Метою екологічного семінару було об'єднання зусиль працівників екослужб, науковців і практиків у дослідженні стану водних ресурсів Кіровоградщини та розробці рекомендацій щодо покращення й формування екологічної свідомості людей шляхом практичної і просвітницької роботи. На семінарі були присутні: заступник директора департаменту екології та природних ресурсів Кіровоградської ОДА; заступник начальника Кіровоградського обласного управління водних ресурсів; голова Кіровоградського обласного осередку громадської організації «Всеукраїнська екологічна ліга»; координатор української природоохоронної громадської організації «еЕкологія» з питань організації громадського контролю в Кіровоградському регіоні; громадський інспектор з охорони навколишнього середовища Державної екологічної інспекції в Кіровоградській області; начальник відділу гідрометеорологічного забезпечення Кіровоградського Центру 3 гідрометеорології; начальник лабораторії Кіровоградського центру гідрометеорології та інші. Виступи учасників семінару були узагальнені й покладені в основу резолюції, серед яких було звернутися до органів влади Кіровоградщини з рекомендаціями щодо посилення контролю за вмістом радіонуклідів у складі питної води, якою забезпечуються жителі регіону, та створення регіональної екологічної лабораторії, оснащеної сучасним обладнанням для оцінки якості питної води та інших компонентів довкілля. Також рекомендувати законодавчій та виконавчій владі розробити й затвердити єдину державну методику оцінки якості водних ресурсів із 
урахуванням міжнародного досвіду та критеріїв впливу (громадського, адміністративного, кримінального) на забруднювачів довкілля.

У тому ж 2016 році спільно на базі Академії представники Google Україна, ГО «е-Екологія» та ГО «Еко-Альянс 4.0» провели навчальний семінар-тренінг у режимі питання/відповідь для природоохоронців міста та області.

Співробітники ЛА НАУ спільно з курсантською та студентською молоддю щорічно проводять суботники, на яких прибирають академічний парк, насаджують нові рослини.

Варто відмітити, що в навчальних планах ЛА НАУ $є$ такі дисципліни, як «Екологія», «Екологія авіаційного транспорту», «Екологічна безпека цивільної авіації». Викладачі щороку публікують наукові доробки, проводять виховну роботу та беруть активну участь в екологічних заходах як в Академії, так і за їі межами.

Ще одним кроком до покращення стану навколишнього середовища в регіоні та залучення ЗВО до цього процесу $є$ написання та реалізація проєктів, створених співробітниками Академії:

$\ddot{y}$ «Створення лабораторії комплексних екологічних досліджень $(R \&$ D) на базі Льотної академії Національного авіаційного університету для потреб регіону», метою якого $\epsilon$ досягнення належного рівня інформаційного забезпечення контролю щодо радіоекологічного стану в Кіровоградській області, розробка рекомендацій та впровадження заходів, що забезпечать мінімізацію впливу іонізуючого випромінювання та максимальний захист здоров'я людини та довкілля;

ӱ «Регіональна система моніторингу шкідливих викидів техногеннонебезпечних об'єктів із використанням безпілотних літальних апаратів», метою якого $€$ створення сучасної інформаційно-аналітичної системи моніторингу забруднення атмосферного повітря техногенними чинниками діяльності видобування та переробки уранових руд в області.

На наше глибоке переконання, формування в молоді дбайливого ставлення до довкілля - ознака цивілізованого суспільства, тому формування екологічної свідомості та культури є вирішальним фактором у гармонізації відносин людини та природи. Упевнені, що тільки спільна праця в екологічній сфері під час розбудови України сприятиме об'єднанню зусиль управлінських інституцій, місцевого самоврядування, науки, освіти, бізнесу та громадськості заради ефективного й комплексного вирішення екологічних проблем нашої країни. 
Висновки та перспективи подальших наукових розвідок. Таким чином, у ході роботи ми проаналізували рівень екологічних знань студентів/курсантів ЗВО М. Кропивницького, описали діяльність Льотної академії НАУ в напрямі формування в молоді, викладачів та співробітників Льотної академії НАУ екологічної свідомості та культури, дбайливого ставлення до довкілля.

Маючи великий досвід, співробітники та керівництво Льотної академії НАУ спрямовують усі свої зусилля на збереження довкілля та формування дбайливого ставлення до нього в освітнього процесі в контексті сталого розвитку.

\section{ЛІТЕРАТУРА}

Білявський, Г. О. (2006). Роль інноваційного потенціалу екологічної освіти і науки в збалансованому розвитку України. Перший Всеукраїнський з'їзд екологів (ECOLOGY-2006): збірник матеріалів Міннародної науково-практичної конференції, Вінниця: УНIBEPCУМ, (c. 289) (Biliavskyi, H. О. (2006). Role of innovative capacity of environmental education and science in sustainable development of Ukraine. First Ukrainian meeting of ecologists (ECOLOGY-2006): proceedings of the International scientific-practical conference, Vinnytsia, 4-7 October, 2006, Vinnytsia: UNIVERSUM, (p. 289)).

Большак, Л. І. (2012). Екологізація освіти як сочіальна потреба сучасного суспільства (автореф. дис. ... канд. філософ. наук: 09.00.10). Київ (Bolshak, L. I. (2012). Greening of education as a social need of modern society (PhD thesis abstract). Kyiv).

Бондарчук, С. В. (2015). Дослідження стану екологічної культури курсантів Кіровоградської льотної академії Національного авіаційного університету Управління високошвидкісними рухомими об'єктами та професійна підготовка операторів складних систем: матеріали III Міжнародної науково-практичної конференції. Кіровоград. Вид-во КЛА НАУ, (с. 1) (Bondarchuk, S. V. (2015). Research of ecological culture state of cadets in Management of high-speed moving objects and professional training of operators of complex systems: materials of the III International scientificpractical conference. Kirovograd. Published by KLA NAU, (p. 1)).

Бондарчук, С. В., Мазур, О.Л. (2009). Дослідження екологічної культури студентів. Интродукция и селекция ароматических и лекарственных растений: международная научно-практическая конференция, посвещенной 200-летию Никитского ботанического сада, Ялта, (сс. 25-26) (Bondarchuk, S. V., Mazur, O. L. (2009). Research of ecological culture of students. Introduction and selection of aromatic and medicinal plants: International scientific-practical conference dedicated to the 200th anniversary of the Nikitsky Botanical Garden, Yalta, (pp. 25-26)).

Варго, О. М. (2006). Екологічна свідомість як умова становлення екологічного суспільства (автореф. дис. ... канд. філософ. наук: 09.00.03). Харків (Varho, О. М. (2006). Ecological consciousness as a condition for the ecological society formation (PhD thesis abstract). Kharkiv).

Киселев, Н.Н. (2008). Экологическая компонента в образовании XXI века. Наука и образование: современные трансформации, (сс. 189-203). Киев: ПАРАПАН (Kiselev, N. N. (2008). Ecological component in the education of XXI century. Science and Education: Modern Transformations, (pp. 189-203). Kyiv: PARAPAN). 
Матеюк, О.П. (2011). Формування професійної екологічної компетентності студентів університету у контексті завдань сталого розвитку. Вісник Національної академії Державної прикордонної служби України. Серія: Педагогічні науки, 1, 91-103 (Mateiuk, O. P. (2011). Formation of professional ecological competence of university students in the context of sustainable development tasks. Bulletin of the National Academy of the State Border Guard Service of Ukraine. Series: Pedagogical Sciences, 1, 91-103).

Про концепцію екологічної освіти в України: рішення колегії Міністерства освіти $і$ науки України № 13/6-19 від 20.12.2001 (On the concept of environmental education in Ukraine: the decision of the board of the Ministry of Education and Science of Ukraine № 13 / 6-19 from 20.12.2001).

Пухальська, Г. А., Дмітрієв, А. О. (2017). Екологічна свідомість і важливість ї̈ формування у майбутніх авіаційних фахівців як психолго-педагогічна проблема. Науковий вісник Льотної академії. Серія: Педагогічні науки, 2, 83-88 (Pukhalska, H. A., Dmitriiev, A. O. Ecological conciousness and the importance of its formation for future aviation specialists as a psychological-pedagogical challenge. Scientific Bulletin of the Flight Academy. Series: Pedagogical Sciences, 2, 83-88).

Саунова, Ю. О. (2005). Формування екологічної свідомості майбутніх учителів (психологопедагогічний аспект). Вісник Житомирського державного університету імені Івана Франка, (25), 209-212 (Saunova, Yu. O. (2005). Environmental awareness-building of future teachers (psychological and pedagogical aspect). Bulletin of Zhytomyr State University named after Ivan Franko, (25), 209-212).

Семитківська, Т., Пухальська, Г., Бондарчук, С. (2017). Технопарк льотної академії Національного авіаційного університету і впровадження інноваційних технологій у сфері екологічної освіти. Екологія /Ecology-2017: матеріали шостого Всеукраїнського з'їзду екологів з міжнародною участю. Вінниця: ВНТУ, 2017, (с. 244) (Semytkivska, T., Pukhalska, H., Bondarchuk, S. (2017). Technological cluster of Flight Academy of the National Aviation University for introduction of innovative solutions in the area of environmental education. Ecology-2017: Proceedings of the Sixth All-Ukrainian Congress of Ecologists with International Participation. Vinnytsia: VNTU, 2017, (р. 244)).

Складановська, М. Г. (2008). Компетентнісний підхід до вивчення проблем екологічної освіти у вищій школі. Вісник Севдту, Вип. 90, 52-56 (Skladanovska, М. H. (2008). Competence-based approach to the study of a problem on environmental education in higher education institutions. Bulletin of SevSTU, Issue 90, 52-56.)

Туниця, Ю. Ю. (2015). Про екологізацію вищої освіти України з метою підготовки фахівців для сталого розвитку: доповідна зап. колегії М-ва освіти і науки України, 10.11.2015 p. Науковий вісник Нлту України, Вип. 25.10, 9-14 (Tunytsia, Yu. Yu. (2015). On ecologization of higher education in Ukraine towards specialist training for sustainable development, 10.11.2015 r. Scientific bulletin of NLTU of Ukraine, Issue 25.10, 9-14).

Льотна академія Національного авіаційного університету (Flight Academy of National Aviation University). Retrieved from: https://zakon.rada.gov.ua/go/v6-19290-01

Громадська організація «Еко Альянс 4.0» (Civic Organization «Eco-Alliance 4.0»). Retrieved from: https:// ww w. facebook.com/groups/1485482475114698/. 


\section{PEЗЮME}

Бондарчук Светлана. K вопросу о формировании бережного отношения к окружающей среде будущих авиационных специалистов в процессе профессиональной подготовки.

В статье рассмотрены пути формирования бережного отношения $к$ окружающей среде будущих авиационных специалистов в процессе профрессиональной подготовки. Рассмотрено место высшей школы в устойчивом развитии. Проанализированы работы современных ученых, занимавшихся исследованием указанной тематики. На примере Летной академии Национального авиационного университета предложено рассмотреть становление бережного, неравнодушного отношения к окружающей среде путем экологизации образования и проведения различных экологических мероприятий через активное привлечение курсантов/студентов к этому процессу. Предложены пути решения проблемы.

Ключевые слова, окружающая среда, устойчивое развитие, образовательный процесс, экологизация образования, авиационные специалисты, экологическая культура, экологическое сознание.

\section{SUM MARY}

Bondarchuk Svitlana. On the issue of forming environmental friendliness of future aviation specialists in the process of their professional training.

Introduction, It is obvious that modern Ukrainian society is developing in accordance with sustainable development, but the specificity of our state is the inconsistency between great plans and reality. Because of this, in our opinion, environmental problems occur and the most important among them, in contrast to the global trend, are current environmental problems of Ukraine which are mainly caused by the inconsistency in the processes of educational, economic and natural resource development.

Analysis of relevant research, A lot of modern Ukrainian scientists have dealt with the issues of education greening, formation of ecological consciousness, studying the competence approach to the problem of ecological education in higher education institutions, formation of professional ecological competence of university students in the context of sustainable development tasks, formation of ecological culture and ecological competence. But in practice, the issues of education greening remain unresolved, namely the practical implementation of the forming environmental culture idea, thinking, consciousness during the educational process in higher education institutions.

Aim of the Study. The aim of the research is to determine the ways of forming a caring attitude to the future aviation specialists' environment at Flight Academy of the National Aviation University in the professional training process.

Research Methods. To achieve the goal such scientific methods as analysis, synthesis, the empirical method have been used in the research.

Results. Over the past 10 years, we have conducted an analysis of the environmental knowledge level among students and cadets of education institutions in Kropyvnytskyi, which showed that young people do not have a thorough, systematic knowledge of the nature laws, the environment connections.

We believe that solving the problem of caring for environment by the future aviation professionals in the training process is possible, among other things, with the help of:

1) conducting "greening" of all subjects, using intersubject connections, and this can be done when the teacher himself will have environmental thinking, trained (retrained) in the spirit of the environmental component of sustainable development;

2) returning "Environmental Safety of Civil Aviation" to the obligatory subjects for studying in higher education institutions; 
3) introduction of the subject "Environmental Safety of Civil Aviation" into the curricula of all specializations of Flight Academy of the National Aviation University;

4 ) development of subject programs with the maximum approximation of ecological knowledge to the specifics of the student/cadet's professional activity;

5) creation of ecological management of educational innovations in higher education institutions;

6) development and implementation of the sustainable environmental concept development in education institutions, the ultimate goal of which may be to obtain the title of "Green University".

This definition is used to determine the environmental level of higher education institutions in the EU ("sustainability" or "greencampus").

To our deep conviction, it is a sign of a civilized society existence when we form a careful attitude to environment among young people, so environmental awareness-building and culture is instrumental in harmonizing of a man and nature relationship. We are confident that only a collaborative work in the environmental sphere in Ukraine development will help to unite efforts of administrative institutions, municipal government, science, education, business and public for the benefit of effective and comprehensive decision of environmental problems of this country.

Conclusions. Summing up in the course of our research we analyzed the level of students and cadets' ecological knowledge in Kropyvnytskyi, we described the activities of Flight Academy of the National Aviation University in the process of environmental awareness and culture formation for youth, teachers and staff of Flight Academy of the National Aviation University.

Having a great experience, staff and authorities of Flight Academy are focusing all their efforts on environment preserving and forming a careful attitude towards it in the educational process.

Key words: environment, sustainable development, educational process, greening education, aviation specialists, ecological culture, ecological consciousness.

\section{удк 378.018.8:373.5.011.3-051]:159.923.5}

Тетяна Григоренко

Уманський державного педагогічний університет імені Павла Тичини ORCID ID 0000-0002-4616-6853

DOI 10.24139/2312-5993/2020.09/130-140

\section{ФОРМУВАННЯ МАЙБУТНЬОГО ВЧИТЕЛЯ-ФІЛОЛОГА В УМОВАХ ОСВІТНЬО- КОМУНІКАТИВНОГО СЕРЕДОВИЩА ЗВО}

У статті виявлено недооцінювання потенціалу зВО щодо забезпечення можливостей формування профресійної компетентності студентів-фрілологів в умовах освітньо-комунікативного середовища. Визначено напрями формування майбутнього вчителя-фрілолога в умовах освітньо-комунікативного середовища 3 ВО. Акцентовано увагу на міждисциплінарному аспекті професійної підготовки вчителяфілолога, адже складовими змісту такої підготовки є творче поєднання фрілологічної й педагогічної освіти. Обгрунтовано створення комунікативно-освітнього середовища, що забезпечує максимальний ступінь індивідуалізації, формування стійких пізнавальних інтересів і мотивів у студентів, скорочення часу на освоєння 